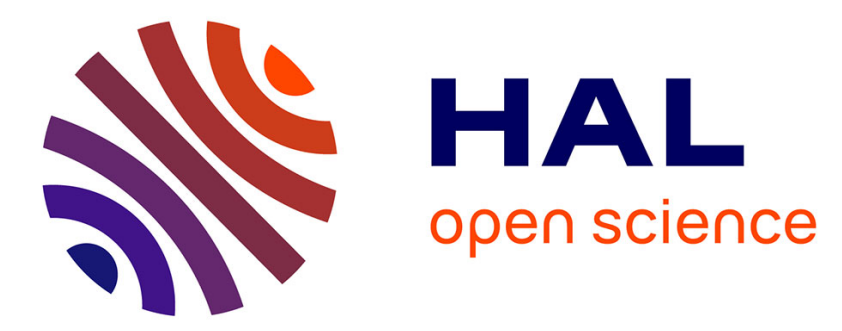

\title{
Foraging ecology drives mercury contamination in chick gulls from the English Channel
}

\author{
Lukasz J Binkowski, Jérôme Fort, Maud Brault-Favrou, Fabrice Gallien, \\ Gilles Leguillou, Olivier Chastel, Paco Bustamante
}

\section{- To cite this version:}

Lukasz J Binkowski, Jérôme Fort, Maud Brault-Favrou, Fabrice Gallien, Gilles Leguillou, et al.. Foraging ecology drives mercury contamination in chick gulls from the English Channel. Chemosphere, 2021, 267, pp.128622. 10.1016/j.chemosphere.2020.128622 . hal-02987558

\section{HAL Id: hal-02987558 \\ https://hal.science/hal-02987558}

Submitted on 3 Nov 2020

HAL is a multi-disciplinary open access archive for the deposit and dissemination of scientific research documents, whether they are published or not. The documents may come from teaching and research institutions in France or abroad, or from public or private research centers.
L'archive ouverte pluridisciplinaire HAL, est destinée au dépôt et à la diffusion de documents scientifiques de niveau recherche, publiés ou non, émanant des établissements d'enseignement et de recherche français ou étrangers, des laboratoires publics ou privés. 


\section{Foraging ecology drives mercury contamination in chick gulls from the English Channel}

Lukasz J. Binkowski ${ }^{\mathrm{a}}$, Jérôme Fort ${ }^{\mathrm{b}}$, Maud Brault-Favrou ${ }^{\mathrm{b}}$, Fabrice Gallien ${ }^{\mathrm{c}}$, Gilles Leguillou ${ }^{\mathrm{d}}$, Olivier Chastel ${ }^{\mathrm{e}}$, Paco Bustamante $\mathrm{b}^{\mathrm{b}, \mathrm{f}}$

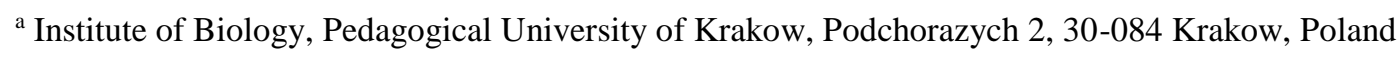

${ }^{\mathrm{b}}$ Littoral, Environnement et Sociétés (LIENSs), UMR 7266 CNRS - La Rochelle Université, 2 rue Olympe de Gouges, 17000 La Rochelle, France

${ }^{\mathrm{c}}$ Groupe Ornithologique Normand, 181 rue d'Auge, 14000 Caen, France

${ }^{\mathrm{d}}$ Maison de l'estuaire, 20 rue Jean Caurret, 76600 Le Havre, France

e Centre d'Etudes Biologiques de Chizé (CEBC), UMR 7372 CNRS-La Rochelle Université, 79360 Villiers en Bois, France

${ }^{\mathrm{f}}$ Institut Universitaire de France (IUF), 1 rue Descartes 75005 Paris, France

\section{Highlights}

- Wide variations in $\mathrm{Hg}$ concentrations were found between the different species of gull

- $\mathrm{Hg}$ concentrations were the highest in Great black-backed gulls

- $\mathrm{Hg}$ exposure was different among the colonies of Great black-backed gull

- Regardless of the breeding site, $\delta^{15} \mathrm{~N}$ explained $\mathrm{Hg}$ concentrations

- Feeding habitat (proxied by $\delta^{34} \mathrm{~S}$ ) has a major influence on $\mathrm{Hg}$ concentrations 


\begin{abstract}
Although mercury $(\mathrm{Hg})$ occurs naturally, human activity is currently the greatest source of release and the ocean receives $\mathrm{Hg}$ inputs by rivers and atmospheric deposition. Seabirds including chicks serve as valuable bioindicators of $\mathrm{Hg}$ contamination, reflecting local contamination around the colony. This study investigates the ecological drivers (trophic position and foraging habitat) influencing $\mathrm{Hg}$ concentrations in blood and feathers of chicks of three sympatric marine gull species. Chicks were sampled between 2015 and 2017 in the Seine estuary, one of the most $\mathrm{Hg}$ contaminated rivers in Europe, and in the Normand-Breton Gulf (the Chausey Islands), $200 \mathrm{~km}$ west, as a reference site with limited contaminant inputs. The trophic status of the chicks was evaluated based on the relative abundance of stable isotopes $\left(\delta^{13} \mathrm{C}, \delta^{15} \mathrm{~N}\right.$ and $\left.\delta^{34} \mathrm{~S}\right)$. There was a tight correlation between $\mathrm{Hg}$ concentrations, as well as the abundance of stable isotopes, in blood and feathers. Great black-backed gull had the highest blood $\mathrm{Hg}$ concentrations of the species $(1.80 \pm 0.92 \mu \mathrm{g} \cdot \mathrm{g}-1$ dry weight $(\mathrm{dw}))$; the Lesser black-backed gull had intermediate concentrations $(0.61 \pm 0.18 \mu \mathrm{g} \cdot \mathrm{g}-1 \mathrm{dw})$; and the European herring gull had the lowest $(0.37 \pm 0.26 \mu \mathrm{g} \cdot \mathrm{g}-1 \mathrm{dw})$. Individuals with the highest trophic position showed consistently the highest $\mathrm{Hg}$ concentrations. The positive relationship between $\mathrm{Hg}$ concentrations and the feeding habitat (marine vs terrestrial) indicated that the main source of $\mathrm{Hg}$ for gulls in the English Channel is marine prey. This exposure led to relatively high $\mathrm{Hg}$ concentrations in Great black-backed gull, which may produce toxic effects to individuals with potential consequences for their populations.
\end{abstract}




\section{Introduction}

Inorganic mercury (iHg), released by volcanism and soil erosion, occurs naturally in marine and coastal ecosystems (Chen et al. 2018). However, $\mathrm{Hg}$ is also released in large amounts by anthropogenic activity, the main sources being industry, the burning of fossil fuels and evaporation by artisanal gold mining (UNEP 2013; Eagles-Smith et al. 2018). Micro-organisms such as sulfato-reducing bacteria have the potential to transform $\mathrm{iHg}$ into methyl-mercury (MeHg) which is highly bioavailable for biota (Compeau and Barta, 1985). MeHg is also one of the most toxic metallic compounds (Wolfe et al. 1998), exerting deleterious effects, such as endocrine disruption and neurodevelopmental impairment in species at the top of the food webs (e.g., Wolfe et al. 1998, Dietz et al. 2013, Tartu et al. 2013). Unlike inorganic forms, MeHg efficiently biomagnifies along the food chains and bioaccumulates in organisms as a result of its high bioavailability and retention in biota (Dijkstra et al. 2013; Harding et al. 2018; Riisgård and Hansen, 1990). For these reasons, $\mathrm{Hg}$ contamination is a priority issue on a global scale for the United Nations, which adopted the Minamata Convention on Hg to protect human health and the environment from anthropogenic emissions (Gustin et al. 2016).

Seabirds are meso and top predators and therefore highly exposed to $\mathrm{Hg}$ due to bioaccumulation (concentrations increase over time in the body) and biomagnification (concentrations increase at each trophic level) processes. They are consequently good bioindicators of $\mathrm{Hg}$ contamination of marine ecosystems, and more particularly of their feeding habitats (e.g. coastal, pelagic, benthic) which may vary among the species feeding there (Furness and Camphuysen, 1997; Ochoa-Acuña et al. 2002; Carravieri et al. 2016). Investigating seabird Hg contamination is vital both for their conservation policies (Goutte et al. 2014ab) and for the monitoring of $\mathrm{Hg}$ contamination in the marine environment (UN Environment 2019). Since it allows non-lethal sampling, researchers often use blood and feathers to determine seabird exposure to $\mathrm{Hg}$, although concentrations measured in these tissues depend on a variety of factors, such as the 
trophic position, the foraging range and the feeding habitat, and also the migration patterns (Carravieri et al 2014; Cherel et al. 2018; Albert et al. 2019). This variability of factors means that it is the blood and feathers of chicks that reflect local contamination of the food webs more clearly than adults', since they are fed by their parents on prey caught in the vicinity of the nesting site (Blévin et al. 2013; Carravieri et al. 2020). These tissues also allow us to access to ecological information regarding birds' diets (i.e. the trophic position reflected by $\delta^{15} \mathrm{~N}$ ) and the origin of their prey (i.e. the feeding habitat reflected by both $\delta^{13} \mathrm{C}$ and $\delta^{34} \mathrm{~S}$ ) (Cherel et al. 2018; Gongora et al. 2018).

The French coasts of the English Channel are significantly affected by $\mathrm{Hg}$ contamination, in particular from the Seine estuary (Cossa et al. 2003; Meybeck et al. 2007). In this area, $\mathrm{Hg}$ contamination has been documented for organisms of low trophic levels (e.g. reaching 0.35 $\mu \mathrm{g} \cdot \mathrm{g}^{-1} \mathrm{dw}$ in shrimps; Cossa et al. 2003) and for marine mammals (e.g. reaching $55 \mu \mathrm{g} \mathrm{g}{ }^{-1} \mathrm{dw}$ in liver of harbour porpoises; Lahaye et al. 2007), but to the best of our knowledge, no data are available for seabirds in the literature. In that context, the main aim of this study was to investigate $\mathrm{Hg}$ concentrations in the blood and feathers of the chicks of different sympatric seabird species from sites variously influenced at different degrees by $\mathrm{Hg}$ and human activity. To this end, we focused on three gull species: the European herring gull (Larus argentatus), the Lesser black-backed gull (L. fuscus graellsii) and the Great black-backed gull (L. marinus), all breeding along the French coast of the English Channel: in the Seine estuary (two breeding sites influenced by high $\mathrm{Hg}$ levels from the Seine river and potential access to anthropogenic food) and in the Normand-Breton gulf (one breeding site uninfluenced by specific, known $\mathrm{Hg}$ sources and intense human activity). We checked the hypotheses that $\mathrm{Hg}$ contamination in birds depends on 1) the location of the colony, 2) the trophic position of the species and 3) the feeding habitat (marine vs terrestrial). We predicted that $\mathrm{Hg}$ concentrations are influenced by the trophic position of individuals (using $\delta^{15} \mathrm{~N}$ as a proxy) both at the interspecific and intraspecific levels, 
as a result of $\mathrm{Hg}$ biomagnification in food webs. We also predicted that $\mathrm{Hg}$ concentrations are related to the quality of the habitat (using $\delta^{13} \mathrm{C}$ and $\delta^{34} \mathrm{~S}$ as its proxies) with individuals feeding on marine prey having higher exposure as a result of higher methylation rates and longer food chains than in terrestrial systems (Lavoie et al. 2013).

\section{Materials and methods}

\section{Sampling sites and sample collection}

Fieldwork was carried out in three areas along the coast of the English Channel (Figure 1). Two sampling sites were located in the Seine estuary (highly urbanized and polluted area), approximately $8 \mathrm{~km}$ apart: the city of Le Havre (N49 $\left.29^{\prime}, \mathrm{E} 0^{\circ} 12^{\prime}\right)$, where nests were distributed across the city on the roofs of buildings, and the Ratier Island (N49 $\left.25^{\prime} 46^{\prime \prime}, \mathrm{E} 0^{\circ} 08^{\prime} 7^{\prime \prime}\right)$, where nests were built on the ground of an island located at the heart of the estuary. The third site was situated $200 \mathrm{~km}$ west of the Seine estuary in the Normand-Breton Gulf and is at a good distance from industrial activity: the Chausey Islands (N48 $\left.53^{\prime}, \mathrm{W} 1^{\circ} 49^{\prime}\right)$, where nests were built on the ground on different islands).

Sampling occurred in the last week of June and first week of July of three consecutive years beginning in 2015 (Table 1). A total of 174 chicks (approximately two months old) of three species of gulls were captured. Herring gull (hereafter EHG) and Great black-backed gull (hereafter GBBG) were sampled in both the Seine estuary and the Chausey Islands while Lesser black-backed gulls (hereafter LBBG) were sampled only in the City of Le Havre. These sympatric species differ significantly in their foraging ecology. Although they are all opportunistic, GBBG is clearly the most predatory, feeding on fish, invertebrates, refuse and other birds while EHG is the most plastic in food preferences and on disturbed environments easily shifts from offshore and onshore food to anthropogenic sources (Threlfall 1968; Ewins et al. 1994; Rail and Chapdelaine 2000). 
From each bird, five ventral feathers were pulled and $2 \mathrm{~mL}$ of blood were collected from the brachial vein using a heparinized syringe and a $25 \mathrm{G}$ needle to determine total $\mathrm{Hg}$ concentrations, the relative abundance of carbon $(\mathrm{C})$, nitrogen $(\mathrm{N})$, and sulfur $(\mathrm{S})$ isotopes, and the sex of the chicks. After collection, whole blood was cooled to $4^{\circ} \mathrm{C}$ and within less than 2 hours of sampling, it was spun at $4000 \mathrm{rpm}$ for 6 minutes at $4^{\circ} \mathrm{C}$ to separate red blood cells for $\mathrm{Hg}$ and isotope analyses and plasma for Persistent Organic Pollutant analyses (data not shown). For this study, only red blood cells were used which were stored frozen $\left(-80^{\circ} \mathrm{C}\right)$ until laboratory analyses.

\section{Molecular sexing}

Molecular sexing was conducted at the Centre d'Etudes Biologiques de Chizé (CEBC), France. Chicks were sexed from blood cells by polymerase chain reaction amplification of part of two highly conserved genes (CHD) present in sexual chromosomes as described in Fridolfsson and Ellegren (1999).

\section{Analysis of $\mathrm{Hg}$ and stable isotopes}

Blood cell (hereafter blood) samples were freeze-dried for 48 hours and ground to powder. The tips of the calami were removed from the feathers to avoid any contamination from the dermic papilla, and the feathers were cleaned with a solution of chloroform/methanol (ratio $2: 1 \mathrm{v} / \mathrm{v}$ ) followed by methanol rinsing. Clean feathers were dried for 48 hours at $45^{\circ} \mathrm{C}$ and cut to tiny pieces with steel scissor for homogenization (Carravieri et al. 2013).

The relative abundance of stable isotopes $(\mathrm{C}, \mathrm{N}$ and $\mathrm{S}$ ) were measured in $\sim 0.3 \mathrm{mg}$ and $\sim 0.6 \mathrm{mg}$ aliquots of blood and feathers respectively, using a continuous flow mass spectrometer (Thermo Scientific Delta V Plus) coupled to an elemental analyzer (Thermo Scientific EA Flash 2000). Isotopic data were presented as standard delta $(\delta)$ notation as parts per mil (\%) deviation 
relative to international standards (Vienna PeeDee Belemnite for $\mathrm{C}$, atmospheric $\mathrm{N}_{2}$ for $\mathrm{N}$, and Vienna-Canyon Diablo Troilite for $S$ ) in accordance with the formula: $\delta^{13} \mathrm{C}, \delta^{15} \mathrm{~N}$ or $\delta^{34} \mathrm{~S}=$ $\left[\left(\mathrm{R}_{\text {sample }} / \mathrm{R}_{\text {standard }}\right)-1\right] \times 10^{3}$, where $\mathrm{R}$ is ${ }^{13} \mathrm{C} /{ }^{12} \mathrm{C},{ }^{15} \mathrm{~N} /{ }^{14} \mathrm{~N}$ or ${ }^{34} \mathrm{~S} /{ }^{32} \mathrm{~S}$, respectively. Analytical precision for $\mathrm{C}, \mathrm{N}$ and $\mathrm{S}$ isotopes was always better than $0.10,015$ and $0.20 \%$ respectively, for repeated measurements of laboratory standards: USGS-61 (Caffeine) and USGS-62 (Caffeine) for both C and N, and USGS-42 (human hair) and IAEA-S2 (silver sulfide) for S.

Total $\mathrm{Hg}$ (hereafter $\mathrm{Hg}$ ) concentrations were measured in blood and feathers using an atomic absorption spectrophotometer (Altec AMA-254) on aliquots weighing 2-5 mg as described by Chouvelon et al. (2009). Briefly, analysis included burning the organic matrix at a temperature of $750^{\circ} \mathrm{C}$, bounding $\mathrm{Hg}$ evaporated by amalgamation on a gold trap, freeing $\mathrm{Hg}$ from amalgamate by heating it and finally measuring the absorption at $253.65 \mathrm{~nm}$. All analyses were repeated 2-3 times until an SD for two measurements below 10\% was acquired. The mean of these two measurements, expressed as $\mu \mathrm{g} \cdot \mathrm{g}^{-1}$ dry weight (dw), was considered for further statistical analyses. The accuracy and reproducibility of $\mathrm{Hg}$ measurements were assessed by the analyses of blanks and certified reference material (CRM) TORT-2 Lobster Hepatopancreas (NRC, Canada; certified mercury concentration: $0.27 \pm 0.06 \mu \mathrm{g} \cdot \mathrm{g}^{-1} \mathrm{dw}$ ). The CRM were analyzed at the beginning and at the end of each analytical cycle, and every 10 samples (Bustamante et al. 2008). The mass of the CRM was adjusted to represent an amount of $\mathrm{Hg}$ similar to that in the samples. Our measured values for the CRM were $0.25 \pm 0.01 \mu \mathrm{g} \cdot \mathrm{g}^{-1} \mathrm{dw}$ $(n=42)$ showing a recovery of $93 \pm 2 \%$. Blanks were analyzed at the beginning of each set of samples and the quantification limit of the method was $0.01 \mathrm{ng} \mathrm{Hg}$.

\section{Statistical analysis}

All the statistical procedures and tests were run with R 3.5.2 (R Core Team, 2018) using Tidyverse (Wickham, 2019) and AICcmodavg packages (Mazerolle, 2019). The significance 
level was established at $\alpha=0.05$. Prior to statistical analyses, data were scrutinized graphically to identify their distribution. Since the distribution of $\mathrm{Hg}$ concentrations was right-skewed, the concentrations were used further as log-transformed. To establish the final form of statistical protocol, we ran a preliminary data inquiry. As we found no statistical differences in any variable between the sexes (one-way ANOVA) and the study did not focus particularly on temporal trends, we pooled the data for both factors across their levels. In respect to obvious differences between species, we ran separate analyses for each species studied.

We ran two separate analyses: on a smaller-scale (within the Seine Estuary) using data from all three species studied from the city of Le Havre and Ratier Island, and on a larger-scale using data from EHG and GBBG from the Seine Estuary (pooled) and the Chausey Islands (excluding LBBG, which was collected solely in the Seine estuary). In both cases, general linear models (GLM) were used with $\log \mathrm{Hg}$ concentrations as dependent variable, site as discrete explanatory variable and isotopic values as continuous explanatory variables. All the continuous explanatory variables $\left(\delta^{13} \mathrm{C}, \delta^{15} \mathrm{~N}, \delta^{34} \mathrm{~S}\right)$ were tightly correlated in most cases (Table $\mathrm{S} 1$ ), so separate GLM models with particular isotopes were built. The analysis was done separately for each species. We built a set of models and used Akaike's Information Criterion corrected for small sample sizes (AICc) to identify the best models.

We also used $\delta^{13} \mathrm{C}, \delta^{15} \mathrm{~N}$ and $\delta^{34} \mathrm{~S}$ values to study the isotopic space used by each species at the three breeding sites, with Stable Isotope Bayesian Ellipses in R package (SIBER) (Jackson et al. 2011). The standard ellipses were drawn containing approximately $40 \%$ of the data (level $=$ 0.4). The standard ellipse area corrected for small sample size (SEAc) was calculated. Posterior estimates of the Bayesian standard ellipse area (SEAb) were then used to test for differences in the isotopic niche width. 


\section{Results}

$\mathrm{Hg}$ concentrations were higher than the limit of detection in all the samples analyzed. Mean $\mathrm{Hg}$ concentrations were higher in chick feathers $\left(0.41-14.49 \mu \mathrm{g} \cdot \mathrm{g}^{-1} \mathrm{dw}\right)$ than in chick blood $(0.05$ $-4.30 \mu \mathrm{g} \cdot \mathrm{g}^{-1} \mathrm{dw}$ ), and both variables were tightly correlated (Figure S1, Table S1) as were the ratios of stable isotopes (Table $\mathrm{S} 1$ ). All further analyses on $\mathrm{Hg}$ and stable isotopes values were therefore carried out on blood only to avoid repetitions. The data set obtained for feathers is presented in the Supplementary Material (Table S2).

\section{Comparisons within the Seine estuary}

In the Seine estuary, $\mathrm{Hg}$ concentrations in EHG (Table 1) were positively related to $\delta^{15} \mathrm{~N}$ and influenced by the site factor $(\mathrm{p}<0.01$ and $\mathrm{p}=0.03$ respectively; Figure 2, Table 2). For GBBG, higher values on Ratier Island (contrarily to EHG) were explained by the same factors (for both $\mathrm{p}<0.01)$. Since for GBBG correlations between $\delta^{15} \mathrm{~N}, \delta^{34} \mathrm{~S}$ and $\delta^{13} \mathrm{C}$ isotopic values were low (Table S5), additional models including all the isotopes were constructed. The best model confirmed former observations that $\mathrm{Hg}$ concentrations were significantly influenced by $\delta^{15} \mathrm{~N}$ and site only $(\mathrm{p}<0.01$ and $\mathrm{p}=0.05$ respectively). In the case of $\mathrm{LBBG}, \mathrm{Hg}$ concentrations appeared to be best explained by $\delta^{13} \mathrm{C}$ (slope $=0.09$, intercept $=1.60, \mathrm{p}<0.01$; Figure 2, Table 2 ). The highest $\mathrm{Hg}$ concentrations among chick gulls were noted in the blood of GBBG, regardless of the site, with $1.56 \pm 0.74 \mu \mathrm{g} \cdot \mathrm{g}^{-1} \mathrm{dw}$ in the city of Le Havre and $1.38 \pm 0.27 \mu \mathrm{g} \cdot \mathrm{g} \mathrm{g}^{-1} \mathrm{dw}$ on Ratier Island. In contrast, EHG showed the lowest concentrations at both sites with $0.33 \pm 0.25 \mu \mathrm{g} \cdot \mathrm{g}^{-1}$ $\mathrm{dw}$ in the city of Le Havre and $0.47 \pm 0.32 \mu \mathrm{g} \cdot \mathrm{g}^{-1} \mathrm{dw}$ on Ratier Island. For the single colony of LBBG situated in the city of Le Havre, $\mathrm{Hg}$ concentrations $\left(0.61 \pm 0.18 \mu \mathrm{g} \cdot \mathrm{g}^{-1} \mathrm{dw}\right)$ were intermediate between the two other species (Table 1). 
Comparisons between the Seine estuary and the Chausey Islands show that $\mathrm{Hg}$ concentrations were positively related to $\delta^{15} \mathrm{~N}$ and additionally influenced by the site factor $(\mathrm{p}<0.01$ for both, Table 3). Regardless of the site, EHG had consistently lower $\mathrm{Hg}$ concentrations in the blood than GBBG (Table 1). For EHG, $\mathrm{Hg}$ reached similar concentrations at both sites $\left(0.37 \mu \mathrm{g} \cdot \mathrm{g}^{-1}\right.$ $\mathrm{dw}$ ), but for GBBG concentrations measured on the Chausey Islands were significantly higher (3.10 vs $1.48 \mu \mathrm{g} \cdot \mathrm{g}^{-1} \mathrm{dw}$ ) than in the Seine Estuary (Figure 2, Table 1).

\section{Isotopic niches}

The values for the three isotopes considered were lower in the blood of EHG than the other species at all sites, while values measured for GBBG were consistently the highest. The stable isotope values in the blood of LBBG fell between the two other species (Figure 2, Table 1). The relationships between isotope values had different strengths depending on the species and the sites (Figure 3 and Figure S2). With the exception of GBBG chicks from Ratier Island, stable isotope values were correlated positively. The biggest SEAb were generally observed in EHG in Ratier Island (mean $9.72 \%^{2}$ ) followed by LBBG in the city of le Havre (mean $6.69 \%^{2}$; Table 4). All the differences for particular relationships among all the sites (one-way ANOVAs $\mathrm{p}<0.01$ ) and all the species (one-way ANOVAs $\mathrm{p}<0.01$ ) were statistically significant (Table 4).

\section{Discussion}

We found that, regardless of the site, $\mathrm{Hg}$ concentrations were highest in GBBG and lowest in EHG. In the Seine Estuary, there was no clear relationship between the location of the colony and $\mathrm{Hg}$ concentrations (e.g. the higher mean was noted for EHG in the city of Le Havre, but for GBBG on Ratier Island), suggesting that the feeding habits of the parents are more important than the sampling site of the chicks in this respect. Along the French coast of the English 
Channel and in the Seine Estuary, $\delta^{15} \mathrm{~N}$ and the site were equally important factors in explaining $\mathrm{Hg}$ concentrations. The only exception was LBBG, whose $\mathrm{Hg}$ concentrations were best explained by $\delta^{13} \mathrm{C}$. This study is the first to report $\mathrm{Hg}$ concentrations in the chicks of these species from the French coasts and to make the link with their trophic ecology.

\section{Hg contamination of the gull community}

In seabirds, food represents the main pathway of exposure to $\mathrm{Hg}$, so these predators reflect the Hg contamination of their food webs (Lavoie et al. 2013). Regardless of the geographic area, high $\mathrm{Hg}$ concentrations in seabirds are frequent in both adults and chicks (Carravieri et al. 2014, 2020). Studies from the same area, however, tended to reveal lower concentrations in chicks than in adults (Carravieri et al. 2014; Mallory et al. 2018; Kucharska et al. 2019), so comparison should be made within the same age group. Overall, the literature offers little information on chicks, so comparisons are usually compelled to include different species. Importantly, because chicks are fed with prey captured in the vicinity of the colony, $\mathrm{Hg}$ concentrations in either their blood or their feathers reflect local contamination (Blévin et al. 2013). In this study, $\mathrm{Hg}$ concentrations in blood and feathers were strongly correlated, indicating that both tissues are relevant in a survey of $\mathrm{Hg}$ exposure. In the present study, only blood $\mathrm{Hg}$ concentrations will be further discussed.

Generally, chick blood $\mathrm{Hg}$ concentrations remain below $1 \mu \mathrm{g} \cdot \mathrm{g}^{-1} \mathrm{dw}$, but those in our study were higher. For instance, $\mathrm{Hg}$ concentrations in the blood of the American Herring gull chicks (Larus smithsonianus) from New York Bight (USA) reached different values in different years with 0.32 and $0.42 \mu \mathrm{g} \cdot \mathrm{g}^{-1} \mathrm{dw}$ (recalculated as others from ww to dw based on $79.13 \%$ of water content; Eagles-Smith et al. 2008; Burger and Gochfeld, 1997). Hg concentrations in the blood of California gull chicks (Larus californicus) from San Francisco Bay (USA) were comparable with $0.34 \mu \mathrm{g} \cdot \mathrm{g}^{-1} \mathrm{dw}$ (Peterson et al. 2017). Common gull chicks (Larus canus) from different 
parts of Germany revealed $\mathrm{Hg}$ concentrations in blood ranging from 0.28 to $0.40 \mu \mathrm{g} \cdot \mathrm{g}^{-1} \mathrm{dw}$ (Kahle and Becker, 1999). In a study of 13 species of birds from the southern Indian Ocean (Carravieri et al. 2020), Hg concentrations in chicks' blood also remained below that of GBBG chicks from the Chausey Islands. These comparisons suggest that concentrations noted along the French coast of the English Channel, especially for GBBG, were high and due to the high toxicity of $\mathrm{Hg}$ already documented, should be compared with toxicity data.

Toxicity thresholds are usually established for adult birds and are further extrapolated to include nestlings. Such inferences, however, may be biased, since chicks have a different efficiency of physiological processes and may thus not react to $\mathrm{Hg}$ toxicity in the same way as adults. Laboratory and field studies of adult birds indicated that concentrations above $14.4 \mu \mathrm{g} \cdot \mathrm{g}^{-1} \mathrm{dw}$ (recalculated from $3.0 \mu \mathrm{g} \cdot \mathrm{g}^{-1} \mathrm{ww}$ ) or averaging $2 \mu \mathrm{g} \cdot \mathrm{g}^{-1} \mathrm{dw}$ in common loons (Gavia immer) and male snow petrels (Pagodroma nivea), respectively, induce adverse effects (Evers et al. 2008; Tartu et al. 2015), highlighting that sensitivity to $\mathrm{Hg}$ is species-specific (Heinz et al. 2009). Even concentrations as low as $1 \mu \mathrm{g} \cdot \mathrm{g}^{-1} \mathrm{dw}$ in blood may induce toxic effects by, for instance, a negative relationship with thiobarbituric acid activity (TBARs) (Custer et al. 2000). Because $88 \%$ of the GBBG chicks from the Seine estuary and the Chausey islands have blood concentrations above this value, a question of the toxicological effects of $\mathrm{Hg}$ on these individuals arises. More generally, the impact of $\mathrm{Hg}$ contamination on the physiology, reproduction, survival and population dynamics of Larus gull populations highlights the need for further investigations in order to determine the biomarkers of effects and assess the toxicological impacts.

\section{Comparisons in the Seine Estuary and farther afield}

In the Seine Estuary environmental conditions were very similar at both sites (the city of Le Havre and Ratier Island), so differences observed were clearly linked to discrepancies between 
the species. Both study sites in the Seine estuary are also close enough to suspect reasonably that birds form both colonies may forage in the same locations. Interestingly, GBBG displayed the highest $\mathrm{Hg}$ concentrations, followed by LBBG and EHG. These results are consistent with previous observations of GBBG and EHG along the Baltic coast of Poland (Szumiło-Pilarska et al. 2016) and with the ecology of these species. Even both species are generalist as explained previously, GBBG also feeds other birds (e.g., Gilliland et al.2004) and competes with LBBG and EHG, and is suspected of contributing to their decline (e.g. Rome and Ellis 2004). Although we did not investigate the prey fed to gull chicks directly, $\delta^{15} \mathrm{~N}$ values and standard ellipse shapes (Figure 5, Table 4) confirm that GBBG tend to feed at higher trophic levels than LBBG and EHG. Moreover, $\delta^{34} \mathrm{~S}$ values also indicate that GBBG specialize more on marine prey than the other species (Hobson 1999). Along with the trophic position (proxied with $\delta^{15} \mathrm{~N}$ ), we observed an increase in $\mathrm{Hg}$ concentrations in the blood (Figure 2). This indicates that $\mathrm{Hg}$ was biomagnified in the gull community of the English Channel.

Larger-scale comparison mainly included the aspects of urbanization and spatial pollution. Part of the study was carried out in highly urbanized areas within the Seine Estuary. The Seine River is also one of the most polluted rivers in Europe with decreasing, but still significant contamination with $\mathrm{Hg}$ (Hamzeh et al. 2013). The Chausey Islands are on the other hand a remote area with no direct sources of $\mathrm{Hg}$, where seabird exposure is likely to be linked to their marine food. In contrast to our prediction (i.e. higher $\mathrm{Hg}$ concentrations in birds from the Seine Estuary), $\mathrm{Hg}$ concentrations in EHG were comparable in the two regions and GBBG was significantly higher on the Chausey Islands. The relatively small SEAb and high blood $\delta^{34} \mathrm{~S}$ values in birds from the Chausey Islands indicate that birds breeding at this latter site occupied a much smaller trophic niche, and thus fed on a smaller range of prey and within more restricted habitats. These differences most likely reflect the lower diversity of food and feeding grounds available in the Chausey Islands, limited to marine prey (Table 1, Table 4 and Figure 3). In 
contrast, in the Seine Estuary, where a large mosaic of habitats are available along the terrestrial-marine continuum, EHG seems to feed on more species of coastal prey (indicated by lower $\delta^{34} \mathrm{~S}$ values) and GBBG on prey lower in the food chain (indicated by lower $\delta^{15} \mathrm{~N}$ values)

(Figure 3). This explains higher $\mathrm{Hg}$ concentrations in GBBG and in the Chausey Islands, since prey and habitat choices are known to influence $\mathrm{Hg}$ exposure, with marine diet and higher trophic levels leading to enhanced exposure (Ochoa-Acuña et al. 2002).

\section{Conclusions}

Thanks to the examination of the chicks of three different gull species from three colonies on the French coast of the English Channel, we provide the first data for gull chick contamination with $\mathrm{Hg}$ in the region and geographic variations comparing a contaminated site (the Seine Estuary) and a reference site (the Chausey Islands). Irrespective of the site, GBBG consistently showed the highest $\mathrm{Hg}$ concentrations. As the blood $\mathrm{Hg}$ concentrations in blood were often above the toxicity threshold, they may produce toxic effects, deserving of further investigations. With the exception of LBBG, $\delta^{15} \mathrm{~N}$ was the most important factor explaining $\mathrm{Hg}$ concentrations in the Seine Estuary, meaning that the exposure to $\mathrm{Hg}$ is closely linked to the trophic position of the birds. A wider perspective showed that, as well as site and trophic position, the feeding habitat indicated by $\delta^{34} \mathrm{~S}$ values, also appear to be an important driver in $\mathrm{Hg}$ exposure. Considering the Seine estuary alone and the French coast of the English Channel as a whole, the biomagnification of $\mathrm{Hg}$ was observed in both cases. Chicks' exposure to $\mathrm{Hg}$ was clearly driven by the feeding ecology of the species studied. As the concentrations of $\mathrm{Hg}$ in blood were above the toxicity threshold, they may produce toxic effects, deserving further investigations. 


\section{Acknowledgements}

The authors thank the GIP Seine Aval for funding the project ECOTONES "Effets de la COnTamination sur les OrgaNismes de l'Estuaire de la Seine" and B. Xuereb as the PI of this project for his support. The permit for the collection of samples was number SRE-UEP2015/363-051-001. We thank C. Ribout from CEBC for processing the molecular sexing. The authors are also grateful to the Plateforme Analyses Élémentaires of LIENSs laboratory for access to their analytical facilities and to G. Guillou from the Plateforme Analyses Isotopiques of LIENSs laboratory for running isotope analyses. The authors also thank the CPER (Contrat de Projet Etat-Région) and the FEDER (European regional Development Fund) for funding the AMA and IR-MS devices. They also thank the Institut Universitaire de France (IUF) for its support to P. Bustamante as a Senior Member. L.J. Binkowski's stay at LIENSs was funded by the French Government Scholarship program 2018.

\section{References}

Ackerman J.T., Eagles-Smith C.A., Herzog M.P., Hartman C.A., Peterson S.H., Evers D.C., Jackson A.K., Elliott J.E., Vander Pol S.S., Bryan C.E. 2016. Avian mercury exposure and risk across western North America: a synthesis. Sci. Total Environ. 568: 749-769. DOI: 10.1016/j.scitotenv.2016.03.071

Albert C., Renedo M., Bustamante P., Fort J. 2019. Using blood and feathers to investigate large-scale $\mathrm{Hg}$ contamination in Arctic seabirds: A review. Environ. Res. 177: 108588. DOI: $10.1016 /$ j.envres.2019.108588

Binkowski Ł.J., Meissner W. 2013. Levels of metals in blood samples from Mallards (Anas platyrhynchos) from urban areas in Poland. Environ. Pollut. 178: 336-342. DOI: 10.1016/j.envpol.2013.03.030

Blévin P., Carravieri A., Jaeger A., Chastel O., Bustamante P., Cherel Y. 2013. Wide range of mercury contamination in chicks of Southern Ocean seabirds. PloS ONE 8: e54508. DOI : 10.1371/journal.pone.0054508

Braune B.M., Gaskin D.E. 1987. Mercury levels in Bonaparte's Gulls (Larus philadelphia) during autumn molt in the Quoddy region, New Brunswick, Canada. Arch. Environ. Contam. Toxicol. 16: 539-549. DOI: 10.2307/3676891

Burger J., Gochfeld M. 1997. Age differences in metals in the blood of Herring (Larus argentatus) and Franklin's (Larus pipixcan) Gulls. Arch. Environ. Contam. Toxicol. 33: 436-440. DOI: $10.1007 / \mathrm{s} 002449900274$ 
Bustamante P., González A.F., Rocha F., Miramand P., Guerra A. 2008. Metal and metalloid concentrations in the giant squid Architeuthis dux from Iberian waters. Mar. Environ. Res. 66(2): 278-287. DOI: 10.1016/j.marenvres.2008.04.003

Carravieri A., Bustamante P., Churlaud C., Cherel Y. 2013. Penguins as bioindicators of mercury contamination in the Southern Ocean: Birds from the Kerguelen Islands as a case study. Sci. Total Environ. 454-455: 141-148. DOI: 10.1016/j.scitotenv.2013.02.060

Carravieri A., Cherel Y., Blévin P., Brault-Favrou M., Chastel O., Bustamante P. 2014. Mercury exposure in a large subantarctic avian community. Environ. Pollut. 190: 51-57. DOI: 10.1016/j.envpol.2014.03.017

Carravieri A., Bustamante P., Labadie P., Budzinski H., Chastel O., Cherel Y. 2020. Trace elements and persistent organic pollutants in chicks of 13 seabird species from Antarctica to the subtropics. Environ. Intern. 134: 105225. DOI: 10.1016/j.envint.2019.105225

Chen C.Y., Driscoll T., Eagles-Smith C.A., Eckley C.S., Gay D.A., Hsu-Kim H., Keane S.E., Kirk J.L., Mason R.P., Obrist D., Selin H., Selin N.E., Thompson M.R. 2018. A critical time for mercury science to inform global policy. Environ. Sci. Technol. 52(17): 95569561. DOI: 10.1021/acs.est.8b02286

Cherel Y., Parenteau C., Bustamante P., Bost C.A. 2018. Stable isotopes document the winter foraging ecology of king penguins and highlight connectivity between subantarctic and Antarctic ecosystems. Ecol. Evol. 8(5): 2752-2765. DOI: 10.1002/ece3.3883

Chouvelon T., Warnau M., Churlaud C., Bustamante P. 2009. Hg concentrations and related risk assessment in coral reef crustaceans, molluscs and fish from New Caledonia. Environ. Pollut. 157(1): 331-340. DOI: 10.1016/j.envpol.2008.06.027

Compeau G.C., Bartha R. 1985. Sulphate reducing bacteria: Principal Methylators of Mercury in Anoxic Estuarine Sediment. Appl. Environ. Microbiol. 50: 498-502.

Cossa D., Laurier F.J.G., Ficht A. 2003. Mercury contamination in the Seine estuary, France: an overview. In: Cai Y., Braids O.C. (Eds.). Biogeochemistry of Environmentally Important Elements. American Chemical Society, Washington, DC, pp. 298-320. DOI: 10.1021/bk-2003-0835.ch020

Custer T.W., Custer C.M., Hines R.K., Sparks D.W., Melancon M.J., Hoffman D.J., Bickham J., Wickliffe J.K. 2000. Mixed-function oxygenases, oxidative stress, and chromosomal damage measured in lesser scaup wintering on the Indiana Harbor Canal. Arch. Environ. Contam. Toxicol. 38: 522-529. DOI: 10.1007/s002449910068

Dietz R., Sonne C., Basu N., Braune B., O’Hara T., Letcher R.J., Scheuhammer T., Andersen M., Andreasen C., Andriashek D., Asmund G., Aubail A., Baagøe H., Born E.W., Chan H.M., Derocher A.E., Grandjean P., Knott K., Kirkegaard M., Krey A., Lunn N., Messier F., Obbard M., Olsen M.T., Ostertag S., Peacock E., Renzoni A., Rigét F.F., Skaare J.U., Stern G., Stirling I., Taylor M., Wiig Ø., Wilson S., Aars J. 2013. What are the toxicological effects of mercury in Arctic biota? Sci. Total Environ. 443: 775-790. DOI: 10.1016/j.scitotenv.2012.11.046

Dijkstra J.A., Buckman K.L., Ward D., Evans D.W., Dionne M., Chen C.Y. 2013. Experimental and natural warming elevates mercury concentrations in estuarine fish. PloS ONE 8: e58401. DOI: 10.1371/journal.pone.0058401

Eagles-Smith C.A., Ackerman J.T., Adelsbach T.L., Takekawa J.Y., Miles A.K., Keister R.A. 2008. Mercury correlations among six tissues for four waterbird species breeding in San Francisco Bay, California, USA. Environ. Toxicol. Chem. 27: 2136-2153. DOI: 


\section{$10.1897 / 08-038.1$}

Eagles-Smith C.A., Ackerman J.T., de La Cruz S.E.W., Takekawa J.Y. 2009. Mercury bioaccumulation and risk to three waterbird foraging guilds is influenced by foraging ecology and breeding stage. Environ. Pollut. 157: 1993-2002. DOI: 10.1016/j.envpol.2009.03.030

Eagles-Smith C.A., Silbergeld E.K., Basu N., Bustamante P., Diaz-Barriga F., Hopkins W.A., Kidd K.A., Nyland J.F. 2018. Modulators of mercury risk to wildlife and humans in the context of rapid global change. Ambio 47: 170-197. DOI: 10.1007/s 13280-017-1011-x

Evers D.C., Savoy L.J., DeSorbo C.R., Yates D.E., Hanson W., Taylor K.M., Siegel L.S., Cooley J.H., Bank M.S., Major A., Munney K., Mower B.F., Vogel H.S., Schoch N., Pokras M., Goodale M.W., Fair J. 2008. Adverse effects from environmental mercury loads on breeding common loons. Ecotoxicol. 17: 69-81. DOI: 10.1007/s10646-007-01687

Ewins P.J., Weseloh D.V, Groom J.H., Dobos R.Z., Mineau P. 1994. The diet of Herring Gulls (Larus argentatus) during winter and early spring on the lower Great Lakes. Hydrobiol. 279-280: 39-55. DOI: 10.1007/BF00027839

Fridolfsson A.-K., Ellegren H. 1999. A simple and universal method for molecular sexing of non-ratite birds. J. Avian Biol. 30: 116-121. DOI: 10.2307/3677252

Furness R., Camphuysen K.C.J. 1997. Seabirds as monitors of the marine environment. ICES J. Mar. Sci. 54: 726-737. DOI: 10.1006/jmsc.1997.0243

Gibson L.A., Lavoie R.A., Bissegger S., Campbell L.M., Langlois V.S. 2014. A positive correlation between mercury and oxidative stress-related gene expression (GPX3 and GSTM3) is measured in female Double-crested Cormorant blood. Ecotoxicol. 23: 10041014. DOI: $10.1007 / \mathrm{s} 10646-014-1243-5$

Gilliland S.G., Ankney C.D., Hicklin P.W. 2004. Foraging ecology of Great Black-backed Gulls during brood-rearing in the Bay of Fundy, New Brunswick. Can. J. Zool. 82(9): 1416-1426. doi:10.1139/z04-124.

Góngora E., Braune B.M., Elliott K.H. 2018. Nitrogen and sulfur isotopes predict variation in mercury levels in Arctic seabird prey. Mar. Pollut. Bull. 135: 907-914. DOI: 10.1016/j.marpolbul.2018.07.075

Goutte A., Bustamante P., Barbraud C., Delord K., Weimerskirch H., Chastel O. 2014a. Demographic responses to mercury exposure in two closely related Antarctic top predators. Ecol. 95: 1075-1086. DOI: 10.1890/13-1229.1

Goutte A., Bustamante P., Barbraud C., Delord K., Weimeskirch H., Chastel O. 2014b. Demographic responses to mercury exposure in two closely-related Antarctic top predators. Ecology 95: 1075-1086. DOI: 10.1890/13-1229.

Gustin M.S., Evers D.C., Bank M.S., Hammerschmidt C.R., Pierce A., Basu N., Blum J., Bustamante P., Chen C., Driscoll C.T., Horvat M., Jaffe D., Pacyna J., Pirrone N., Selin N. 2016. Importance of integration and implementation of emerging and future mercury research into the Minamata Convention. Environ. Sci. Technol. 50: 2767-2770. DOI: 10.1021/acs.est.6b00573

Hamzeh M., Ouddane B., El-Daye M., Halwani J. 2013. Profile of trace metals accumulation in core sediment from Seine river estuary (docks basin). Environ. Technol. 34: 1107-1116. DOI: $10.1080 / 09593330.2012 .736539$ 
Harding G., Dalziel J., Vass P. 2018. Bioaccumulation of methylmercury within the marine food web of the outer Bay of Fundy, Gulf of Maine. PLoS ONE 13: e0197220. DOI: 10.1371/journal.pone.0197220

Heinz G.H., Hoffman D.J., Klimstra J.D., Stebbins K.R., Kondrad S.L., Erwin C.A. 2009. Species differences in the sensitivity of avian embryos to methylmercury. Arch. Environ. Contam. Toxicol. 56: 129-138. DOI: 10.1007/s00244-008-9160-3

Hobson K. 1999. Tracing origins and migration of wildlife using stable isotopes: a review. Oecologia 120, 314-326.

Jackson A.L., Inger R., Parnell A.C., Bearhop S. 2011. Comparing isotopic niche widths among and within communities: SIBER - Stable Isotope Bayesian Ellipses in R. J. Anim. Ecol. 80: 595-602. DOI: 10.1111/j.1365-2656.2011.01806.x

Kahle S., Becker P.H. 1999. Bird blood as bioindicator for mercury in the environment. Chemosphere 39: 2451-2457. DOI: 10.1016/S0045-6535(99)00154-X

Kucharska K., Binkowski Ł.J., Batoryna M., Dudzik K., Zaguła G., Stawarz R. 2019. Blood mercury levels in mute swans (Cygnus olor) are not related to sex, but are related to age, with no blood parameter implications. Environ. Pollut. 252: 21-30. DOI: 10.1016/j.envpol.2019.05.075

Lahaye V., Bustamante P., Law R., Learmonth J.A., Santos M.B., Boon J.P., Rogan E., Dabin W., Addink M.J., Lopez A., Zuur A.F., Pierce G.J., Caurant F. 2007. Biological and ecological factors related to trace element levels in harbour porpoises (Phocoena phocoena) from European waters. Mar. Environ. Res. 64: 247-268. DOI: 10.1016/j.marenvres.2007.01.005

Lavoie R.A., Jardine T.D., Chumchal M.M., Kidd K.A., Campbell L.M. 2013. Biomagnification of mercury in aquatic food webs: a worldwide meta-analysis. Environ. Sci. Technol. 47: 13385-13394. DOI: 10.1021/es403103t

Mallory M.L., Provencher J.F., Robertson G.J., Braune B.M., Holland E.R., O’Driscoll N.J., Klapstein S., Stevens K. 2018. Mercury concentrations in blood, brain and muscle tissues of coastal and pelagic birds from northeastern Canada. Ecotox. Environ. Safety 157: 424430. DOI: 10.1016/j.ecoenv.2018.04.004

Mazerolle M.J. 2019. AICcmodavg: Model selection and multimodel inference based on (Q)AIC(c). R package version 2.2-2. https://cran.r-project.org/package=AICcmodavg

Meybeck M., Lestel L., Bonté P., Moilleron R., Colin J.L., Rousselot O., Hervé D., de Pontevès C., Grosbois C., Thévenot D.R. 2007. Historical perspective of heavy metals contamination $(\mathrm{Cd}, \mathrm{Cr}, \mathrm{Cu}, \mathrm{Hg}, \mathrm{Pb}, \mathrm{Zn})$ in the Seine River basin (France) following a DPSIR approach (1950-2005). Sci. Total Environ. 375: 204-231. DOI: 10.1016/j.scitotenv.2006.12.017

Ochoa-Acuña H., Sepúlveda M.S., Gross T.S. 2002. Mercury in feathers from Chilean birds: Influence of location, feeding strategy, and taxonomic affiliation. Mar. Pollut. Bull. 44: 340-345. DOI: 10.1016/S0025-326X(01)00280-6

Peterson S.H., Ackerman J.T., Eagles-Smith C.A. 2017. Mercury contamination and stable isotopes reveal variability in foraging ecology of generalist California gulls. Ecol. Indic. 74: 205-215. DOI: 10.1016/j.ecolind.2016.11.025

R Core Team, 2018. R: A language and environment for statistical computing. R Foundation for Statistical Computing, Vienna, Austria. https://www.R-project.org/ 
Rail J.-F., Chapdelaine G. 2000. Diet of herring gull Larus argentatus chicks in the Gulf and Estuary of the St Lawrence River, Quebec, Canada. Atl. Seabirds 2: 19-34.

Riisgård H.U., Hansen S. 1990. Biomagnification of mercury in a marine grazing food-chain: algal cells Phaeodactylum tricornutum, mussels Mytilus edulis and flounders Platichthys flesus studied by means of a stepwise-reduction-CVAA method. Mar. Ecol. Prog. Ser. 62: 259-270.

Robinson S.A., Lajeunesse M.J., Forbes M.R. 2012. Sex differences in mercury contamination of birds: testing multiple hypotheses with meta-analysis. Environ. Sci. Technol. 46: 70947101. DOI: $10.1021 / \mathrm{es} 204032 \mathrm{~m}$

Rome M.S., Ellis J.C. 2004. Foraging Ecology and Interactions between Herring Gulls and Great Black-backed Gulls in New England. Waterbirds 27(2): 200-210. DOI: 10.1675/1524-4695(2004)027[0200:FEAsIBH]2.0.CO;2

Szumiło-Pilarska E., Grajewska A., Falkowska L., Hajdrych J., Meissner W., Fraczek T., Bełdowska M., Bzoma S. 2016. Species differences in total mercury concentration in gulls from the Gulf of Gdansk (Southern Baltic). J. Trace Elem. Med. Biol. 33: 100-109. DOI: 10.1016/j.jtemb.2015.09.005

Tartu S., Goutte A., Bustamante P., Angelier F., Moe B., Clément-Chastel C., Bech C., Gabrielsen G.W., Bustnes J.O., Chastel O. 2013. To breed or not to breed: endocrine response to mercury contamination by an Arctic seabird. Biol. Lett. 9: 20130317. DOI: 10.1098/rsbl.2013.0317

Tartu S., Angelier F., Wingfield J.C., Bustamante P., Labadie P., Budzinski H., Weimerskirch H., Bustnes J.O., Chastel O. 2015. Corticosterone, prolactin and egg neglect behavior in relation to mercury and legacy POPs in a long-lived Antarctic bird. Sci. Total Environ. 505: 180-188. DOI: 10.1016/j.scitotenv.2014.10.008

Threlfall W. 1968. The food of three species of gull in Newfoundland. Canad. Field-Naturalist. 82: $176-180$.

UNEP, 2013. Global Mercury Assessment 2013: Sources, Emissions, Releases, and Environmental Transport. United Nations Environment Programme (UNEP) Chemicals Branch, Geneva, Switzerland.

UNEP, 2019. Global Mercury assessment 2018. UN Environment Programme, Chemicals and Health Branch Geneva, Switzerland.

Wickham H. 2019. Welcome to the tidyverse. J. Open Source Softw. 4(43): 1686. DOI: 10.21105/joss.01686

Wolfe M.F., Schwarzbach S., Sulaiman R.A. 1998. Effects of mercury on wildlife: a comprehensive review. Environ. Toxicol. Chem. 17: 146-160. DOI: 10.1002/etc.5620170203 
Table 1. Total mercury concentrations (mean $\left.\pm \mathrm{SD}, \mu \mathrm{g} \cdot \mathrm{g}^{-1} \mathrm{dw}\right), \delta^{13} \mathrm{C}, \delta^{15} \mathrm{~N}$ and $\delta^{34} \mathrm{~S}$ values (mean \pm SD, \%o), in the blood of chick gulls studied in and outside the Seine Estuary.

\begin{tabular}{|c|c|c|c|c|c|}
\hline \multicolumn{2}{|l|}{ Species } & \multirow{2}{*}{$\begin{array}{l}\text { City of Le Havre } \\
0.32 \pm 0.25\end{array}$} & \multirow{2}{*}{$\frac{\text { Ratier Island }}{0.47 \pm 0.32}$} & \multirow{2}{*}{$\frac{\text { Seine Estuary }}{0.37 \pm 0.28}$} & \multirow{2}{*}{$\begin{array}{l}\text { Chausey Islands } \\
0.37 \pm 0.18\end{array}$} \\
\hline EHG & $\mathrm{Hg}$ & & & & \\
\hline & $\delta^{13} \mathrm{C}$ & $-21.78 \pm 1.22$ & $-21.86 \pm 1.15$ & $-21.80 \pm 1.19$ & $-20.21 \pm 0.62$ \\
\hline & $\delta^{15} \mathrm{~N}$ & $10.17 \pm 1.53$ & $10.51 \pm 1.48$ & $10.28 \pm 1.51$ & $12.10 \pm 0.84$ \\
\hline & $\delta^{34} \mathrm{~S}$ & $9.63 \pm 2.52$ & $9.62 \pm 1.90$ & $9.62 \pm 2.33$ & $14.16 \pm 1.26$ \\
\hline & $\mathrm{N}$ & 39 & 17 & 56 & 16 \\
\hline \multirow[t]{5}{*}{ GBBG } & $\mathrm{Hg}$ & $1.56 \pm 0.74$ & $1.38 \pm 0.27$ & $1.48 \pm 0.60$ & $3.10 \pm 0.92$ \\
\hline & $\delta^{13} \mathrm{C}$ & $-17.87 \pm 0.61$ & $-18.22 \pm 1.12$ & $-18.02 \pm 0.86$ & $-17.40 \pm 0.45$ \\
\hline & $\delta^{15} \mathrm{~N}$ & $14.73 \pm 0.70$ & $15.39 \pm 0.17$ & $15.00 \pm 0.63$ & $15.50 \pm 0.38$ \\
\hline & $\delta^{34} \mathrm{~S}$ & $13.76 \pm 1.02$ & $13.03 \pm 1.19$ & $13.46 \pm 1.14$ & $16.93 \pm 0.48$ \\
\hline & $\mathrm{N}$ & 37 & 26 & 63 & 15 \\
\hline \multirow[t]{5}{*}{ LBBG } & $\mathrm{Hg}$ & $0.61 \pm 0.18$ & - & $0.61 \pm 0.18$ & - \\
\hline & $\delta^{13} \mathrm{C}$ & $-19.55 \pm 1.30$ & - & $-19.55 \pm 1.30$ & - \\
\hline & $\delta^{15} \mathrm{~N}$ & $13.04 \pm 1.54$ & - & $13.04 \pm 1.54$ & - \\
\hline & $\delta^{34} \mathrm{~S}$ & $12.10 \pm 1.58$ & - & $12.10 \pm 1.58$ & - \\
\hline & $\mathrm{N}$ & 24 & 0 & 24 & 0 \\
\hline
\end{tabular}

EHG: European herring gull; GBBG: Great black-backed gull; LBBG: Lesser black-backed gull. 
Table 2. Parameters of GLM and LM (AICc followed by $\mathrm{R}^{2}$ adjusted) * explaining blood $\mathrm{Hg}$ concentrations in chick gulls studied within the Seine Estuary.

\begin{tabular}{llll}
\hline Models & EHG & GBBG & LBBG \\
\hline$\delta^{13} \mathrm{C}$ & $18.87 ; 0.35$ & $-62.31 ; 0.10$ & $\mathbf{- 5 0 . 1 1 ; 0 . 7 1}$ \\
$\delta^{13} \mathrm{C}+$ site & $13.01 ; 0.42$ & $-60.03 ; 0.08$ & - \\
$\delta^{13} \mathrm{C}+$ site(+interactions) & $15.30 ; 0.41$ & $-61.27 ; 0.12$ & - \\
\hline$\delta^{15} \mathrm{~N}$ & $1.45 ; 0.52$ & $-66.89 ; 0.16$ & $-43.44 ; 0.62$ \\
$\delta^{15} \mathrm{~N}+$ site & $\mathbf{- 1 . 3 3 ; 0 . 5 5}$ & $\mathbf{- 7 3 . 1 5} ; \mathbf{0 . 2 5}$ & - \\
$\delta^{15} \mathrm{~N}+$ site $(+$ interactions $)$ & $1.00 ; 0.55$ & $-71.51 ; 0.25$ & - \\
\hline$\delta^{34} \mathrm{~S}$ & $28.14 ; 0.23$ & $-61.84 ; 0.09$ & $-35.81 ; 0.48$ \\
$\delta^{34} \mathrm{~S}+$ site & $24.46 ; 0.29$ & $-59.67 ; 0.08$ & - \\
$\delta^{34} \mathrm{~S}+$ site $(+$ interactions $)$ & $23.12 ; 0.33$ & $-58.96 ; 0.08$ & - \\
\hline$\delta^{13} \mathrm{C}+\delta^{15} \mathrm{~N}+\delta^{34} \mathrm{~S}$ & - & $-68.55 ; 0.21$ & - \\
$\delta^{13} \mathrm{C}+\delta^{15} \mathrm{~N}+\delta^{34} \mathrm{~S}+$ site & - & $-70.46 ; 0.25$ & - \\
$\delta^{13} \mathrm{C}+\delta^{15} \mathrm{~N}+\delta^{34} \mathrm{~S}+$ site & - & $-39.83 ; 0.13$ & - \\
$(+$ all interactions $)$ & & & \\
\hline $\mathrm{B}$ & & & \\
\hline
\end{tabular}

Bolds indicate the best models according to AICc values. EHG: European herring gull; GBBG: Great black-backed gull; LBBG: Lesser black-backed gull. 
Table 3. Parameters of GLM (AICc followed by $\mathrm{R}^{2}$ adjusted) ${ }^{*}$ explaining blood $\mathrm{Hg}$ concentrations in chick gulls studied along the French coast of the English Channel.

\begin{tabular}{lll}
\hline Models & EHG & GBBG \\
\hline site & $43.56 ; 0.00$ & $-70.47 ; 0.42$ \\
\hline$\delta^{13} \mathrm{C}$ & $16.74 ; 0.31$ & $-44.41 ; 0.19$ \\
$\delta^{13} \mathrm{C}+$ site & $13.33 ; 0.35$ & $-79.08 ; 0.49$ \\
$\delta^{13} \mathrm{C}+$ site+all interactions & $15.37 ; 0.34$ & $-80.65 ; 0.51$ \\
\hline$\delta^{15} \mathrm{~N}$ & $-2.09 ; 0.47$ & $-49.96 ; 0.25$ \\
$\delta^{15} \mathrm{~N}+$ site & $\mathbf{- 1 0 . 3 4 ; 0 . 5 3}$ & $\mathbf{- 8 3 . 5 5} \mathbf{0 . 5 2}$ \\
$\delta^{15} \mathrm{~N}+$ site+all interactions & $-8.53 ; 0.53$ & $-82.44 ; 0.52$ \\
\hline$\delta^{34} \mathrm{~S}$ & $28.59 ; 0.18$ & $-73.08 ; 0.44$ \\
$\delta^{34} \mathrm{~S}+$ site & $24.54 ; 0.24$ & $-76.88 ; 0.48$ \\
$\delta^{34} \mathrm{~S}+$ site+all interactions & $26.38 ; 0.24$ & $-76.26 ; 0.48$
\end{tabular}

Bold indicates the best models according to AICc values. EHG: European herring gull; GBBG: Great black-backed gull; LBBG: Lesser black-backed gull. 
Table 4. Mean areas of the isotopic-niche ellipses (SEAb obtained using the Bayesian inference) for gull chicks from all the sites studied (all expressed as $\%{ }^{2}$ ).

\begin{tabular}{lll|lll|ll}
\hline & \multicolumn{2}{c|}{ Chausey Islands } & \multicolumn{3}{c|}{ City of Le Havre } & \multicolumn{2}{c}{ Ratier Island } \\
& EHG & GBBG & EHG & GBBG & LBBG & EHG & GBBG \\
\hline$\delta^{13} \mathrm{C} \sim \delta^{15} \mathrm{~N}$ & $1.09^{\mathrm{a} \#}$ & $0.32^{\mathrm{b \#}}$ & $2.77^{\mathrm{a}^{*}}$ & $\mathbf{0 . 7 7}^{\mathbf{b}^{*}}$ & $\mathbf{4 . 1 1}^{\mathbf{c}}$ & $\mathbf{4 . 7 7}^{\mathrm{a} \&}$ & $0.44^{\mathrm{b} \dagger}$ \\
$\delta^{34} \mathrm{~S} \sim \delta^{15} \mathrm{~N}$ & $2.34^{\mathrm{a} \#}$ & $0.38^{\mathrm{b \#}}$ & $7.34^{\mathrm{a}^{*}}$ & $\mathbf{1 . 1 9}^{\mathbf{b}^{*}}$ & $\mathbf{6 . 6 9}^{\mathrm{c}}$ & $\mathbf{9 . 7 2}^{\mathrm{a} \&}$ & $0.45^{\mathrm{b} \dagger}$ \\
$\delta^{13} \mathrm{C} \sim \delta^{34} \mathrm{~S}$ & $2.28^{\mathrm{a} \#}$ & $0.48^{\mathrm{b \#}}$ & $\mathbf{6 . 2 4}^{\mathrm{a}^{*}}$ & $1.24^{\mathrm{b}^{*}}$ & $\mathbf{6 . 3 0}^{\mathbf{c}}$ & $4.82^{\mathrm{a} \&}$ & $\mathbf{1 . 5 9}^{\mathbf{b} \dagger}$ \\
\hline
\end{tabular}

Bold indicates the greatest values for the species. EHG: European herring gull; GBBG: Great black-backed gull; LBBG: Lesser black-backed gull. Different letters indicate significant differences between species within the given site (ANOVA or t test, $p<0.05$ ). Different symbols indicate significant differences between sites within a given species (ANOVA, $\mathrm{p}<0.05)$. 


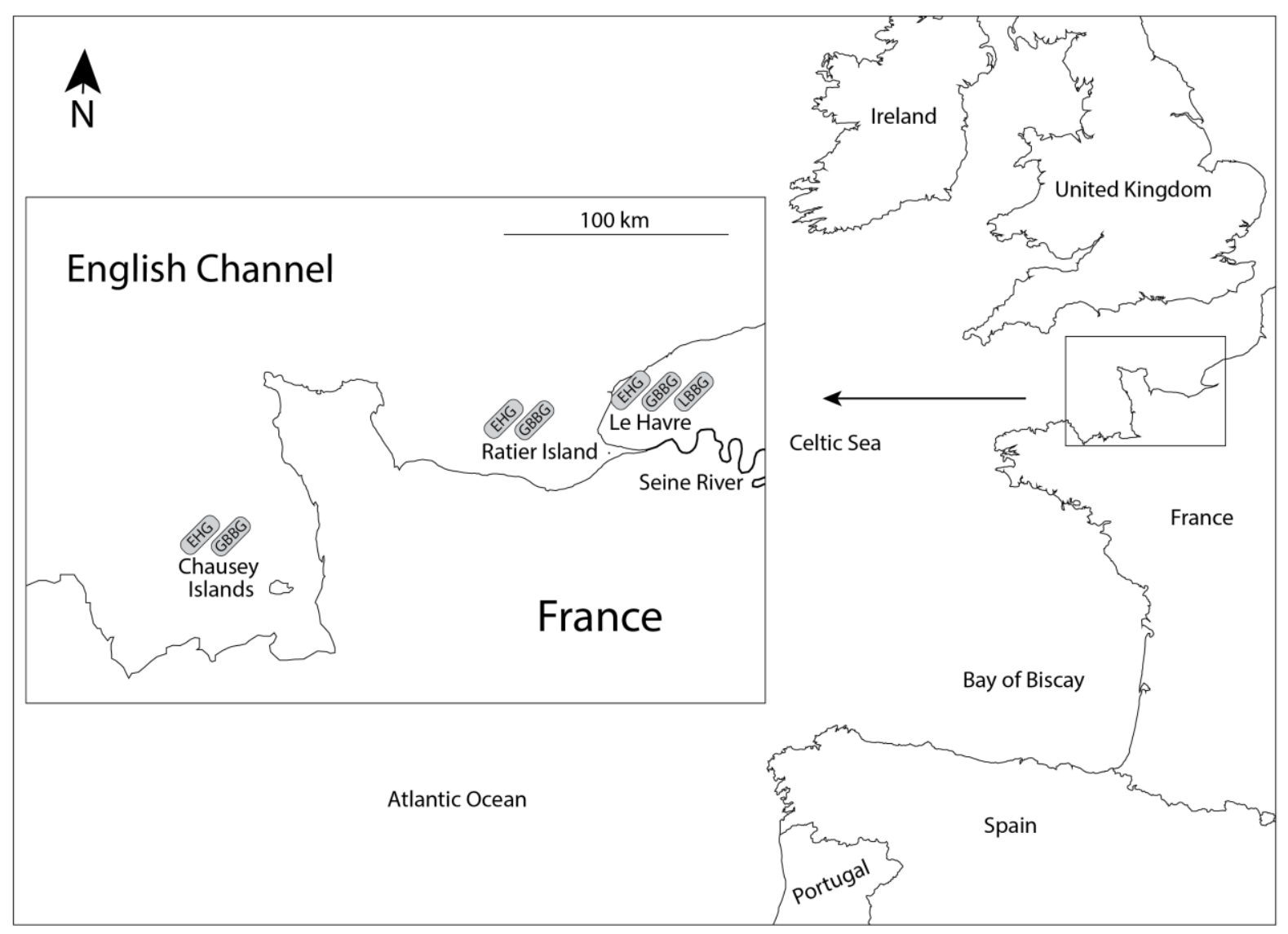

Figure 1. Sampling sites along the French coast of the English Channel: The Chausey Islands and the Seine Estuary with the city of Le Havre and Ratier Island. EHG - European herring gull, GBBG - Great black-backed gull, LBBG - Lesser black-backed gull. 


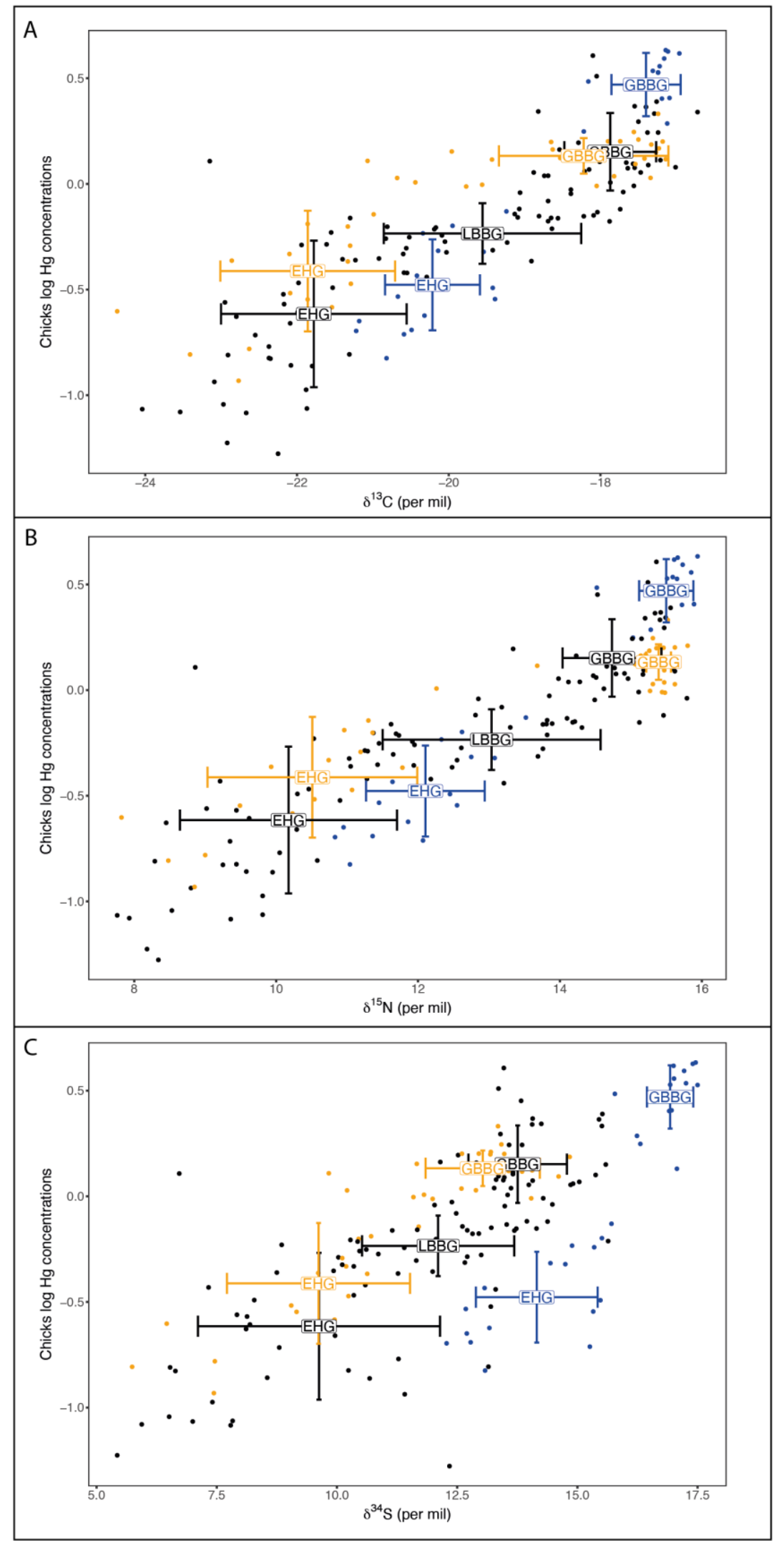

Figure 2. $\mathrm{Hg}$ concentrations in blood as a function of $\delta^{13} \mathrm{C}(\mathrm{A}), \delta^{15} \mathrm{~N}(\mathrm{~B})$ and $\delta^{34} \mathrm{~S}(\mathrm{C})$ values in chick gulls from the French coast of the English Channel (EHG - European herring gull N=72, GBBG - Great black-backed gull N=78, LBBG - Lesser black-backed gull N=24; blue - the Chausey Islands, black - the city of Le Havre, orange - Ratier Island). 


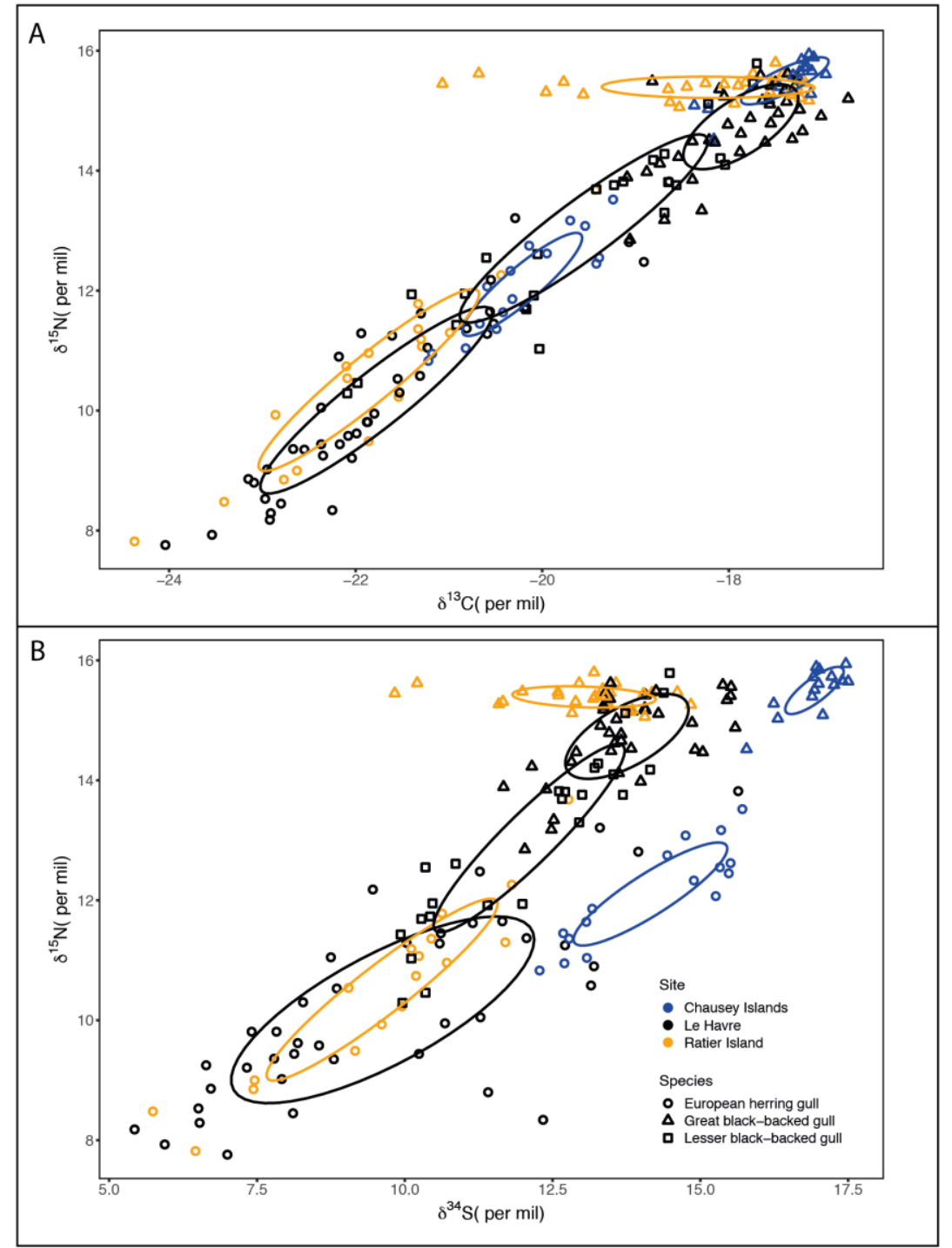

Figure 3. Relationship between $\delta^{15} \mathrm{~N}$ and $\delta^{13} \mathrm{C}(\mathrm{A})$ and $\delta^{34} \mathrm{~S}(\mathrm{~B})$ isotopic values for all the species at all the sites studied, with isotopic-niche standard ellipses. 


\section{Supplementary Material}

Table S1. Total Hg concentrations (mean $\pm \mathrm{SD}, \mu \mathrm{g} \cdot \mathrm{g}^{-1} \mathrm{dw}$ ), relative abundance of isotopes (mean $\pm \mathrm{SD}, \%$ o) in blood and feathers of chick gulls studied along with $\mathrm{r}$ Pearson correlation factors for correlation between both tissues.

\begin{tabular}{llcccc}
\hline Species & Tissue & $\mathrm{Hg}$ & $\delta^{13} \mathrm{C}$ & $\delta^{15} \mathrm{~N}$ & $\delta^{34} \mathrm{~S}$ \\
\hline EHG & blood & $0.37 \pm 0.26$ & $-21.45 \pm 1.27$ & $10.68 \pm 1.58$ & $10.63 \pm 2.85$ \\
& feather & $1.43 \pm 0.78$ & $-19.74 \pm 1.36$ & $12.2 \pm 1.68$ & $8.46 \pm 1.83$ \\
& Pearson $\mathrm{r}$ & 0.807 & 0.972 & 0.971 & 0.886 \\
\hline GBBG & blood & $1.80 \pm 0.92$ & $-17.9 \pm 0.84$ & $15.1 \pm 0.62$ & $14.13 \pm 1.73$ \\
& feather & $6.42 \pm 2.50$ & $-15.97 \pm 0.82$ & $16.64 \pm 0.63$ & $13.76 \pm 1.24$ \\
& Pearson $\mathrm{r}$ & 0.846 & 0.951 & 0.960 & 0.760 \\
\hline LBBG & blood & $0.61 \pm 0.18$ & $-19.56 \pm 1.3$ & $13.04 \pm 1.53$ & $12.1 \pm 1.58$ \\
& feather & $2.62 \pm 0.75$ & $-17.71 \pm 1.34$ & $14.56 \pm 1.46$ & $12.92 \pm 1.78$ \\
& Pearson $\mathrm{r}$ & 0.872 & 0.974 & 0.978 & 0.899 \\
\hline
\end{tabular}

EHG: European herring gull; GBBG: Great black-backed gull; LBBG: Lesser black-backed gull. 
Table S2. Concentrations of total $\mathrm{Hg}\left(\right.$ mean $\left.\pm \mathrm{SD}, \mu \mathrm{g} \cdot \mathrm{g}^{-1} \mathrm{dw}\right), \delta^{13} \mathrm{C}, \delta^{15} \mathrm{~N}$ and $\delta^{34} \mathrm{~S}$ values (mean \pm SD, \%o) in the feathers of the European herring gull, Great black-backed gull and Lesser black-backed gull studied between 2015 and 2017 in the Chausey Islands, the city of Le Havre and Ratier Island.

\begin{tabular}{|c|c|c|c|c|c|}
\hline Species & & City of Le Havre & Ratier Island & Seine Estuary & Chausey Islands \\
\hline \multirow[t]{5}{*}{ EHG } & $\mathrm{Hg}$ & $1.18 \pm 0.64$ & $1.87 \pm 1.01$ & $1.39 \pm 0.83$ & $1.6 \pm 0.58$ \\
\hline & $\delta^{13} \mathrm{C}$ & $-20.19 \pm 1.28$ & $-20.11 \pm 1.13$ & $-20.16 \pm 1.22$ & $-18.25 \pm 0.54$ \\
\hline & $\delta^{15} \mathrm{~N}$ & $11.53 \pm 1.59$ & $12.15 \pm 1.47$ & $11.72 \pm 1.57$ & $13.87 \pm 0.66$ \\
\hline & $\delta^{34} S$ & $8.14 \pm 1.69$ & $8.97 \pm 1.97$ & $8.46 \pm 1.83$ & - \\
\hline & $\mathrm{N}$ & $39(27)$ & $17(17)$ & $56(44)$ & $16(0)$ \\
\hline \multirow[t]{5}{*}{ GBBG } & $\mathrm{Hg}$ & $5.86 \pm 2.62$ & $5.72 \pm 1.39$ & $5.81 \pm 2.2$ & $8.93 \pm 2.05$ \\
\hline & $\delta^{13} \mathrm{C}$ & $-15.95 \pm 0.63$ & $-16.22 \pm 1.15$ & $-16.06 \pm 0.88$ & $-15.61 \pm 0.37$ \\
\hline & $\delta^{15} \mathrm{~N}$ & $16.31 \pm 0.68$ & $16.82 \pm 0.24$ & $16.51 \pm 0.6$ & $17.14 \pm 0.5$ \\
\hline & $\delta^{34} S$ & $13.74 \pm 1.06$ & $13.79 \pm 1.44$ & $13.76 \pm 1.24$ & - \\
\hline & $\mathrm{N}$ & $37(26)$ & $24(24)$ & $61(50)$ & $15(0)$ \\
\hline \multirow[t]{5}{*}{ LBBG } & $\mathrm{Hg}$ & $2.62 \pm 0.75$ & - & $2.62 \pm 0.75$ & - \\
\hline & $\delta^{13} \mathrm{C}$ & $-17.71 \pm 1.34$ & - & $-17.71 \pm 1.34$ & - \\
\hline & $\delta^{15} \mathrm{~N}$ & $14.56 \pm 1.46$ & - & $14.56 \pm 1.46$ & - \\
\hline & $\delta^{34} S$ & $12.92 \pm 1.78$ & - & $12.92 \pm 1.78$ & - \\
\hline & $\mathrm{N}$ & $23(20)$ & - & $23(20)$ & - \\
\hline
\end{tabular}

Sample $\mathrm{N}$ given for $\mathrm{Hg}, \delta^{13} \mathrm{C}$ and $\delta^{15} \mathrm{~N}$ followed by $\mathrm{N}$ for $\delta^{34} \mathrm{~S}$ (in brackets). 
Table S3. Pearson correlation coefficients between isotope concentrations in the blood of chick gulls studied (pooled across sites). All correlations were statistically significant.

\begin{tabular}{llll}
\hline & $\delta^{13} \mathrm{C}$ vs $\delta^{15} \mathrm{~N}$ & $\delta^{13} \mathrm{C}$ vs $\delta^{34} \mathrm{~S}$ & $\delta^{15} \mathrm{~N}$ vs $\delta^{34} \mathrm{~S}$ \\
\hline European herring gull & 0.940 & 0.822 & 0.842 \\
Great black-backed gull & 0.303 & 0.613 & 0.369 \\
Lesser black-backed gull & 0.926 & 0.874 & 0.929 \\
\hline
\end{tabular}




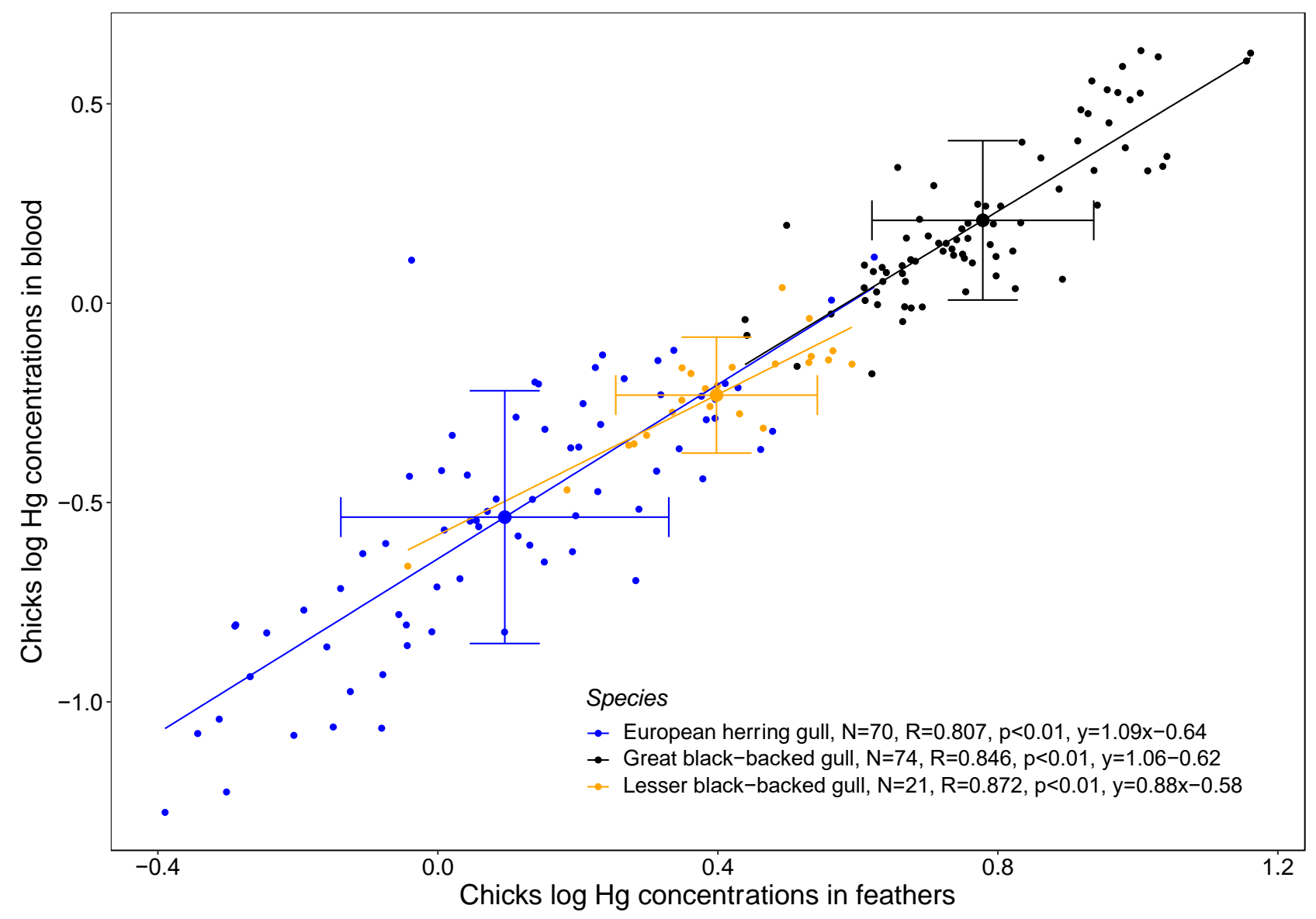

Figure S1. Relationship between $\mathrm{Hg}$ concentrations in the blood and feathers of the chicks of three gull species from the English Channel coast (data from the Seine Estuary and the Chausey Islands were pooled). 


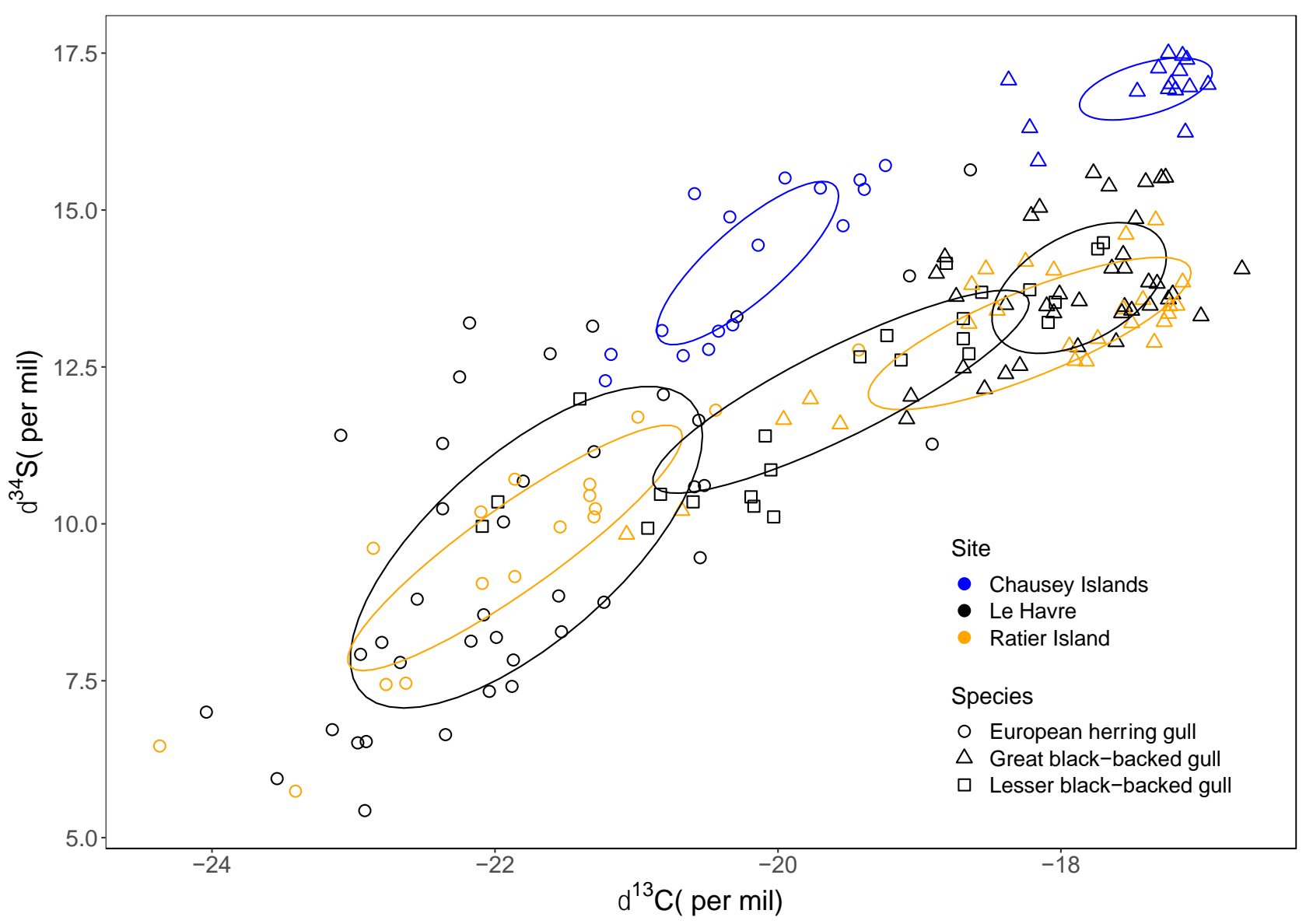

Figure S2. $\delta^{13} \mathrm{C}$ and $\delta^{34} \mathrm{~S}$ isotopic values for all the species at all the sites studied, with isotopicniche standard ellipses. 